\title{
Dynamics of design collaboration: BIM models as intermediary digital objects
}

Paavola, Sami \& Miettinen, Reijo

A draft: Paavola, S., and Miettinen, R. (in press). Computer Supported Cooperative Work (CSCW).

\begin{abstract}
Engineering and architectural design research has studied the uses of various kinds of artefacts and visual representations like sketches, drawings and design plans. The implementation of Building Information Modelling (BIM) creates a new constellation of instruments and calls for further reconceptualising of the collaborative design process. The paper presents analysis of BIM models as co-developed intermediary objects in the design. They function both as objects of joint problem solving and as a concrete but dynamic means for collaboration both virtually and in face-to-face meetings. We suggest that BIM models provide novel forms of 'virtual materiality': in design meetings BIM models provide a tangible means for designers' collaboration. Versatile indexical use of 3D BIM models dominates discussion and problem solving in design meetings.
\end{abstract}

Key Words: Building Information Modelling (BIM); design collaboration; intermediary object, indexicality; digital object; virtual materiality

\section{Introduction}

The extensive use of digital technologies is giving new currency to the discussions on objects and artefacts as means of human interaction. People are using and developing all kinds of digital objects (documents, models, visual representations, etc.) in their work. On the one hand, digital objects seem to have characteristics which separate them from "material" artefacts (Kallinikos, Aaltonen, and Marton, 2010; Ekbia 2009; Yoo et al., 2010). On the other hand, the materiality of digital information has been emphasized (Blanchette 2011; Kallinikos 2002).

In this paper we study how Building Information Modelling (BIM) is changing work and interaction in the design of buildings, and how to take this change into account in the conceptualizations of design collaboration. In particular, we introduce a conception of intermediary object (Vinck and Jeantet, 1995; Vinck 2011) to highlight the evolving nature

of BIM models in design process. BIM provides new, tangible means for collaboration and 
changes the ways how collaboration is organized in construction projects. It refers to new technologies that combine three-dimensional models and quantitative object-related data of the building that can be shared by all stakeholders and used throughout the buildings lifecycle, at least potentially (Eastman, Teicholz, Sacks and Liston, 2011). BIM is also seen as a way of increasing productivity in the construction industry by providing opportunities for enhanced collaboration and information exchange (Becerik-Gerber and Rice, 2010). These promises are partially rhetorical but they also mirror real, incremental changes in construction projects (Miettinen and Paavola, 2014).

Classic ethnographic studies of engineering design have analysed the meaning of artefacts and visual representations (Bucciarelli 1994, 2002; Henderson 1999). Bucciarelli found that different engineering groups have their own specialized language which makes communication across domains difficult. That is why various artefacts such as sketches, models, or diagrams are central in enabling collaboration (Bucciarelli 2002). Henderson (1999) emphasizes the role of visual representations in engineering work. The use of all kinds of visual representations or 'conscription devices' has been seen as the central means of communication and collaboration. Visual representations "allow intangible ideas to become concrete - but still allow ideas to be reworked and renegotiated" (ibid., p. 200). In architectural design Schmidt and Wagner (2004) emphasized an abundance of representational artefacts like CAD plans, and drawings: "It is typical of cooperative work in modern work settings that multiple actors so to speak interact 'through' a collection of artefacts of various kinds" (ibid., p. 350).

In this paper we first present ways in which BIM has been characterized in engineering and design literature. Then we briefly introduce discussions on the role of objects and artefacts in design collaboration to provide a background for understanding how BIM is changing designers' collaboration. We define our own interpretation on the notion of the co-developed intermediary object. It is necessary to understand how BIM models are used in construction projects. We followed designers' and engineers' collaboration in a school renovation project in Finland and examined their use of BIM models. In the paper, we first analyse the two main ways BIM models were used during the project by architects and engineers. Secondly, we analyse in more detail the use of BIM models in face-to-face design meetings. The BIM models used in face-to-face meetings had a strong impact on organizing and structuring designers' interactions, which was shown in the heavy indexical interaction with the BIM models during these meetings. This interaction seems to have many characteristics in common with the way designers collaborate around paper documents. However, the BIM models provide an additional means of making inquiries about design plans. They provide new forms of 'virtual materiality' combining features provided by BIM tools (like zooming and rotating) with strong indexical interaction in the face-to-face meetings.

\section{What is BIM?}


BIM has been defined in several ways in the engineering and management literature. The first one is a "narrow" technical definition, which recognizes three foundational elements of BIM. Firstly, BIM is composed of three-dimensional models that have a long development history in CAD-CAM technologies and product models. Secondly, by using object-related programming quantitative and qualitative data can be attached to the parts of the model. This combination allows not only advanced forms of visualization, but in the future, will also allow simulation and modelling of the behaviour of the building, for example, its energy consumption or lighting as well as the operative management of building projects. Thirdly, a decisive turn towards BIM came with the development of standards that enabled the transfer of information between "native" or disciplinary design software models, that is, architectural, structural and HVAC (heating, ventilation and air conditioning) models. They also enabled the creation of combined models. The most important of these standards, IFC (Industry Foundation Classes), was published in 1997, and the first software was aligned with it in 1999 (Laakso and Kiviniemi, 2012).

BIM implementation has also been introduced as a new way of working collaboratively throughout the whole lifecycle of the building. Models drawn up according to different design disciplines can be united into combined models, which can in principle be used by all stakeholders of a construction project. This has been a foundation for a BIM utopia: all the relevant information about a building project would be presented in one model or data repository to be used by all stakeholders during the whole lifecycle of the building (Miettinen and Paavola, 2014). BIM implementation is expected to improve the quality of information and collaboration, eliminate errors and improve the quality of design (Crotty 2012). Many of these expectations are unrealistic being derived directly from the technical potentialities of the technology. For example, it is recognized that there is an information gap between design and construction on the one hand, and operation and maintenance of the building, on the other (Becerik-Gerber 2010; Korpela, Miettinen, Salmikivi and Ihalainen, 2015).

BIM is also defined as a central means of improving productivity and business results. It is widely agreed that the development of productivity in the construction industry lags behind the development of other industries (Eastman et al., 2011, p. 11). A reason for this is the project-based nature and fragmentation of the construction industry (Bishop et al., 2009). Accordingly, a wide definition of BIM defines it in terms of efficiency and productivity gains (Love et al., 2014). The literature recognizes that BIM implementation calls for changes in design collaboration, such as integrated design, big room, or knotworking (Succar 2009; Alhava et al., 2015), and in contracts such as an alliance contract model (Lahdenperä 2012) as well as in the organization of production often characterized in terms of lean production (Alves and Tsao, 2007).

BIM is an evolving set of instrumentalities that is used for increasing number of specific purposes. Presently, BIM technologies are mainly used in engineers' and 
architects' collaboration. The global development of standards and national decision making concerning the use of BIM in public construction projects influence the implementation. The system developers provide a constant flow of BIM-related software with new functionalities. Firms and public players in construction and facility management configure their own systems and create related capabilities and expertise. Typically, parts and modules developed by several vendors are combined and adjusted to meet the local needs of the users (Davenport 1998, Stewart and Williams, 2005). In each construction project, the participants have to negotiate the uses of BIM tools. BIM can therefore be characterized as an evolving, multifunctional, partially integrated, configurational instrumentality the use of which is re-negotiated in each project.

\section{The use of artefacts and intermediary digital objects in design collaboration}

There is relatively long history of research on artefacts and objects such as visual representations, sketches, drafts, drawings, and prototypes in designing (Henderson 1999; Subrahmanian et al., 2003; Boujut and Blanco, 2003; Schmidt and Wagner, 2004). It has been noted, however, that within design research there have also been strong mentalistic and intellectualist traditions which have not taken material artefacts into account (Schmidt and Wagner, 2002, 2004; Bresnen and Harty, 2010; Kuutti 2011). Theoretical approaches emphasizing the meaning of various kinds of artefacts include actor-network theory (e.g. Henderson 1991, 1999; Vinck and Jeantet, 1995), activity theory (see Kaptelinin and Nardi, 2006, p. 85-89), distributed cognition (Henderson 1999; Schmidt and Wagner, 2004), and in recent discussions sociomateriality (Orlikowski 2007). In her classic works on design, Kathryn Henderson (1999) analysed sketches, prototypes, and all kinds of visual representations as thinking tools for designers ("I can't think without my drafting board") and interactive communication tools.

Information and organizational scientists have analysed the characteristics or properties of digital artefacts (or 'digital objects') that separate them from (or unite them with) other (physical or "material") artefacts. Digital objects (or digital artefacts) have a "dubious ontology" when they do not follow similar criteria to the ones we normally use with physical objects (Ekbia 2009; Hui 2012). Some researchers have emphasized a clear distinction between material and "non-material" objects (Faulkner and Runde, 2011). According to Faulkner and Runde, ICT-related objects are technological objects that "have no intrinsic physical being" although their "bearers" can be material objects (ibid., p. 1-2). Others have emphasized the materiality of digital objects. Leonardi (2010) makes a distinction between three meanings of materiality, that is, as: 1) matter, 2) practical instantiation, and 3) significance. The first meaning, materiality as matter is often emphasized; "materiality" seems to imply tangibility" (ibid.). One can touch "material" objects like desks and walls but data cannot be touched. But according to Leonardi, even if materiality of digital objects is not about physical substance or "stuff" (matter), it is about practical instantiations and significance. 
Specific characteristics of digital objects include editability and distributedness (Kallinikos et al., 2010), their unstable, or unbounded nature (Ekbia 2009, programmability and updatability, communicability, traceability and associability (Yoo et al., 2010, p. 10), as well as modularity and variability. For example, according to Manovich (2001, p. 36), the principle of variability means that ' $[a]$ new media object is not something fixed and for all, but something that can exist in different, potentially infinite versions.' It is the task of empirical research to show the consequences of these properties and how much and in which forms they are expressed in the uses of digital objects.

Many papers have presented analyses of the coordinative role of objects and artefacts in design work (Schmidt and Wagner, 2004; Whyte and Harty, 2012), which is related to deictic or indexical interaction with design artefacts (Tory et al., 2008; Ewenstein and Whyte, 2008). The concept of stigmergy is also used to highlight that coordination is achieved by using the work (itself) accomplished by others (Christensen 2014). Building processes are full of collaboration in which individuals coordinate their work by using physical things done or designed by others. For example, an engineer models the ventilation systems by using the architects' model of the building, and an electrician aligns the wiring based on work done by the carpenter (ibid.). It is not just separate artefacts that operate in coordination but "complexes of interrelated practices and artefacts" (Schmidt and Wagner, 2004). Design artefacts are tangible means of communicating design thinking (Henderson 1999). Design meetings are full of indexical interaction around artefacts, like gesturing, navigating, annotating, viewing (Tory et al., 2008), or pointing, drawing, annotating, reflecting, and talking (Ewenstein and Whyte, 2009). In order to understand the uses of various kinds of artefacts, they should be seen within interrelated activity systems (Deken and Lauche, 2014), as a many-faced phenomenon with multiple uses and roles (Christensen and Harper 2016). Or they should be seen as a part of "habitats" or "ecologies" where the object of design is potentially expanding from design products to technology-enhanced activity spaces (Kaptelinin and Bannon, 2012).

The use of BIM technologies challenges basic conceptions of design collaboration. Ewenstein and Whyte (2009) and others (Whyte and Harty, 2012; Deken and Lauche, 2010,2014 ) have emphasized the multidimensional and evolving nature of objects in the collaborative design of buildings and product development. According to them, visual representations such as sketches embody design knowledge. At the same time, they have an almost 'agential role' in showing what is 'lacking, wanting, and unfolding' in the sketches themselves (Ewenstein and Whyte, 2009, p. 22). In order to find conceptual tools for understanding evolving objects in design, Ewenstein and Whyte made a distinction between 'boundary objects', 'epistemic objects', and 'technical objects' (see ibid., p. 10). They find that visual representations have characteristics of both boundary objects and epistemic objects. The former are usually interpreted as stable and concrete thing-like artefacts, while the latter highlight the dynamic, unfolding nature of the process. Their distinction however, seems to be missing concrete thing-like artefacts or objects, which are at the same time modifiable and editable, or concrete and dynamic. This kind of a use 
is central in designers' collaboration with $\mathrm{BIM}$, and in this article, we call them (codeveloped) intermediary objects (see Table 1).

Table 1. A comparison of characteristics of concepts 'boundary object', 'epistemic object' 'technical object' and '(co-developed) intermediary object'; the first three adapted from Ewenstein and Whyte, 2009, p. 10.

\begin{tabular}{|l|l|l|l|l|}
\hline & $\begin{array}{l}\text { Boundary } \\
\text { object }\end{array}$ & $\begin{array}{l}\text { Epistemic } \\
\text { object }\end{array}$ & $\begin{array}{l}\text { Technical } \\
\text { object }\end{array}$ & $\begin{array}{l}\text { (Co- } \\
\text { developed) } \\
\text { Intermediary } \\
\text { object }\end{array}$ \\
\hline $\begin{array}{l}\text { Nature of the } \\
\text { object }\end{array}$ & $\begin{array}{l}\text { Concrete (e.g. } \\
\text { a timeline of a } \\
\text { project) }\end{array}$ & $\begin{array}{l}\text { Abstract (e.g. a } \\
\text { working } \\
\text { hypothesis of a } \\
\text { research } \\
\text { project) }\end{array}$ & $\begin{array}{l}\text { Concrete (e.g. } \\
\text { an equipment } \\
\text { used in a } \\
\text { project) }\end{array}$ & $\begin{array}{l}\text { Concrete, and } \\
\text { reworkable } \\
\text { (e.g. a } \\
\text { versioned BIM- } \\
\text { model) }\end{array}$ \\
\hline Role over time & $\begin{array}{l}\text { (Relatively) } \\
\text { stable }\end{array}$ & Static & $\begin{array}{l}\text { Modifiable and } \\
\text { versioned }\end{array}$ \\
\hline $\begin{array}{l}\text { Function in } \\
\text { activity }\end{array}$ & $\begin{array}{l}\text { Allow } \\
\text { interoperability } \\
\text { and } \\
\text { communication }\end{array}$ & $\begin{array}{l}\text { Generates new } \\
\text { open questions } \\
\text { and issues for } \\
\text { going further in } \\
\text { the research }\end{array}$ & $\begin{array}{l}\text { A means or an } \\
\text { instrument for } \\
\text { accomplishing } \\
\text { something }\end{array}$ & $\begin{array}{l}\text { Gives tangible } \\
\text { intermediate } \\
\text { means for } \\
\text { working } \\
\text { towards an end } \\
\text { result }\end{array}$ \\
\hline
\end{tabular}

Vinck has used the notion of intermediary object to refer to all objects used, produced, and disseminated in evolving engineering design practices and collaboration networks (see Vinck 2011). It has been used to refer to the use of all kinds of artefacts (like sketches, drawings, models) that have an "active" role in the design process (Eckert and Boujut, 2003; Vinck 2011; Vinck and Jeantet, 1995). It has also referred to the open and evolving nature of the design process with intermediate stages and evolving artefacts instead of design seen as linear and sequential process (Vinck and Jeantet, 1995; Ewenstein and Whyte, 2009; Boujut and Blanco, 2003; Deken and Lauche, 2010, 2014).

Vinck's definition of intermediary object, inspired by actor network theory, refers to all kinds of artefacts in the design process (Vinck 2011, p. 26-28; see also Vinck and Jeantet, 1995, p. 118). We find it reasonable, instead, to connect the term to the activity theoretical concept of "object of activity". It is something given (independent of the subject), to which the activity is directed and, on the other hand, transformed to satisfy a human need (Leontjev 1978, p. 52). In construction design, the final object of activity is a building and its forthcoming uses. Ilyenkov (1977, p. 280) has suggested that in design activity a model or a system of models (or drawings) can be regarded as a 'special object' and an 'ideal image of an object'. In the design work, models and plans are the "special objects" that are moulded and altered without yet modifying the building itself (Miettinen 
and Paavola, in press). Schmidt and Wagner (2004, p. 364) characterize this idea of an intermediary special object in their analysis of CAD plans and drawings in architectural design: "They serve as objectifications of the construction-in-the-making and are, as such, the immediate object of their work, they are what is looked upon, inspected, gestured at, discussed, modified, annotated etc." In comparison to CAD plans and drawings, BIM models bring forth novel kinds of intermediate objectifications used in design collaboration.

Latour (1986) has used the concepts of "inscriptions" and "immutable mobiles" which is a basis for modern culture. Writing, printing and visualizing allow things (like maps or documents) that are easy to move but remain immutable when they are moved. Compared to these, intermediary objects (as we interpret them) are "mutable mobiles" (see also Ewenstein and Whyte, 2009, p. 27). These objects are constructed, versioned and transformed collaboratively. Their nature as digital, modifiable, scalable artefacts contribute to this functionality. In this paper we characterize BIM models as co-developed intermediary objects. The term 'intermediary object' highlights the role of BIM as a tangible means for the designers to be used and transformed in their work. It also refers to those intermediary outcomes of design cycles which are an object of attention and transformation in collaborative design.

The meaning of tangibility has often been emphasized in design collaboration with traditional 2D-tools like visual documents and visual representations (sketches, models, figures, etc.) (Henderson 1991, 1999; Ewenstein and Whyte, 2009). Designers use a variety of visual representations. Ewenstein and Whyte (2009) emphasized the physical, or tactile engagement of designers with these kinds of visual representations in meetings of design teams. These designers mostly used paper drawings which were annotated, referred, pointed, touched, and discussed (see also Tory et al. 2008). This kind of an interaction contains a lot of indexicality ${ }^{1}$. Our analysis focuses on indexical interaction with BIM models. This provides an additional means for discussions on materiality or immateriality of digital objects (see e.g. Yoo et al., 2010; Faulkner and Runde, 2011; Leonardi 2010).

We maintain that co-developed intermediary objects entail novel forms of "virtual materiality". ${ }^{2}$ BIM models are virtual in a sense defined by the pragmatist Charles Peirce. According to Peirce, something is virtual if it has the efficiency ("virtus") of something which is not that something itself (Peirce 1931-1958, CP 6.372). So, accordingly, virtual reality has the efficiency of the reality it represents even if it is not that reality. BIM models are not the same as the building itself but they provide an actual means of investigating and observing features and relationships of the building. Peirce noted that virtual is often confounded with 'potential' even when the meaning is almost the contrary (ibid.). BIM models are models or representations of a building according to which the real building is meant to be constructed. However, they are not only representations of a building to be constructed. They also provide real means of observing from different angles what the plans of the building look like, and to study whether and how the native models of different 
design disciplines work together. BIM models provide virtual materiality by being concrete and tangible in the sense that they can be combined, moved, zoomed, rotated, looked at, and pointed to from different angles using a BIM software. They are not concrete in the same way as an actual building is but they are concrete in the sense of "relating to or characteristic of things capable of being perceived by the senses, as opposed to abstractions" (The Free Dictionary by Farlex). In this paper, we present analysis of how this virtual materiality appeared in one-day design meetings at which BIM models were used.

\section{Case, data, and method}

The research case consisted of the designing process of a renovated school in Eastern Finland during 2011 and 2012. The partners in the construction project knew each other's ways of working quite well and aimed to develop ways of working together. The architectural company had been using BIM for quite a long time in their own work. The project was the first one for the partners in which all designers - the HVAC (heating, ventilation, air conditioning, electricity) engineers and structural engineers - used BIM technologies. The HVAC engineering company had used CAD modelling for several years but they were just learning and developing the uses of BIM. Consequently, they needed to think anew about their collaboration with other designers.

The data analysed for this paper consist of observation of: 1) two one-day design meetings, 2) a planning meeting for BIM use, 3) making a combined model and a clash detection list by the BIM expert, and 4) a session at which the clash detection list was checked by the designers. These meetings were key events (Fetterman 2010) in collaborative uses of BIM models during the project, showing both how BIM models were used, and how different partners saw difficulties in these uses. The key partners were interviewed before the project. Interviews provided background information for the case.

Table 2. Data sources of the study (all videotaped with notes by the researcher)

\begin{tabular}{|l|l|l|l|}
\hline Event & Length & Participants & Analysis \\
\hline $\begin{array}{l}\text { Two one-day } \\
\text { design } \\
\text { meetings }\end{array}$ & 7.5 hours & $\begin{array}{l}\text { Project manager, } \\
\text { main designer, } \\
\text { structural engineer, } \\
\text { HVAC engineers, } \\
\text { representatives of } \\
\text { contractors }\end{array}$ & $\begin{array}{l}\text {-How was the use of BIM } \\
\text { face design meetings)? }\end{array}$ \\
\hline $\begin{array}{l}\text { Planning } \\
\text { meeting for } \\
\text { the BIM use }\end{array}$ & 2 hours 40 min & $\begin{array}{l}\text { BIM expert, project } \\
\text { manager, } \\
\text { engineers and ases of BIM models }\end{array}$ & $\begin{array}{l}\text {-How was the use of BIM } \\
\text { models organized (clash }\end{array}$ \\
\hline
\end{tabular}




\begin{tabular}{|l|l|l|l|}
\hline & & $\begin{array}{l}\text { designers from all } \\
\text { design areas, } \\
\text { representatives of } \\
\text { the contractor }\end{array}$ & $\begin{array}{l}\text { detection)? } \\
\text { produced? }\end{array}$ \\
\hline $\begin{array}{l}\text { Making of a } \\
\text { combined } \\
\text { model }\end{array}$ & 4 hours 10 min & $\begin{array}{l}\text { BIM expert } \\
\text { (explaining at the } \\
\text { same time what he } \\
\text { is doing to the } \\
\text { researcher) }\end{array}$ & $\begin{array}{l}\text {-How was the use of BIM } \\
\text { models organized (clash } \\
\text { detection)? } \\
\text { produced? }\end{array}$ \\
\hline $\begin{array}{l}\text { Clash } \\
\text { detection } \\
\text { meeting }\end{array}$ & 33 min & HVAC engineers (4) & $\begin{array}{l}\text {-How was the use of BIM } \\
\text { models organized (clash } \\
\text { detection)? } \\
\text { produced? }\end{array}$ \\
\hline
\end{tabular}

A central aspect of BIM is the technologies that are used by project partners. The BIM software products used in the project are listed in Table 3. Each of them has specific preplanned functions such as allowing architectural design, calculating energy consumption, viewing the clashes between the models etc. The project participants used nine BIMrelated software packages provided by seven software firms in the design phase.

Table 3. BIM-related software used in a Finnish construction project in 2011-2012.

\begin{tabular}{|c|c|c|c|}
\hline Software & Provider & Main users & $\begin{array}{l}\text { Main uses and } \\
\text { outcomes }\end{array}$ \\
\hline 1. ArchiCAD & $\begin{array}{l}\text { M.A.D., } \\
\text { Finland }\end{array}$ & Architects & Architect model \\
\hline $\begin{array}{l}\text { 2. Tekla } \\
\text { Structures }\end{array}$ & $\begin{array}{l}\text { Tekla, part of } \\
\text { Trimble } \\
\text { Company, } \\
\text { USA }\end{array}$ & Structural engineers & Structural model \\
\hline $\begin{array}{l}\text { 3. Tekla BIM } \\
\text { sight }\end{array}$ & $\begin{array}{l}\text { Tekla, part of } \\
\text { Trimble } \\
\text { Company, } \\
\text { USA }\end{array}$ & $\begin{array}{l}\text { Structural engineers } \\
\text { Architects }\end{array}$ & $\begin{array}{l}\text { Creating } \\
\text { combined models } \\
\text { and checking } \\
\text { compatibility of } \\
\text { the native models } \\
(1 \text { and } 2)\end{array}$ \\
\hline 4. MagiCAD & $\begin{array}{l}\text { Progman Oy, } \\
\text { Finland }\end{array}$ & HVAC engineers & $\begin{array}{l}\text { HVAC-models } \\
\text { (electricity, } \\
\text { plumbing, } \\
\text { ventilation) }\end{array}$ \\
\hline 5. Dialux & $\begin{array}{l}\text { Dial Gmbh, } \\
\text { Germany }\end{array}$ & HVAC engineers & Light design \\
\hline
\end{tabular}




\begin{tabular}{|l|l|l|l|}
\hline 6. NavisWorks & $\begin{array}{l}\text { Autodesk, } \\
\text { USA }\end{array}$ & HVAC engineers & $\begin{array}{l}\text { Combining HVAC } \\
\text { models and } \\
\text { checking } \\
\text { compatibility of } \\
\text { native models (4) }\end{array}$ \\
\hline $\begin{array}{l}\text { 7. Solibri Model } \\
\text { Checker }\end{array}$ & Solibri, Finland & BIM expert & $\begin{array}{l}\text { Creating } \\
\text { combined models } \\
\text { of all native } \\
\text { models and clash } \\
\text { detection lists }\end{array}$ \\
\hline $\begin{array}{l}\text { 8. Solibri Model } \\
\text { Viewer }\end{array}$ & Solibri, Finland & All designers & $\begin{array}{l}\text { Viewing the } \\
\text { clashes (7) }\end{array}$ \\
\hline 9. Riuska & $\begin{array}{l}\text { Granlund Inc., } \\
\text { Finland }\end{array}$ & HVAC engineers & $\begin{array}{l}\text { Energy } \\
\text { simulations }\end{array}$ \\
\hline
\end{tabular}

Each design discipline used its own software to make design models of their own area: ArchiCAD (used by the architects); Tekla structures (used by the structural engineers); and MaciCAD, and Dialux (used by the HVAC engineers). They were tools for producing what are called 'native models': architectural, structural and HVAC models. These 'native models' could be used to unite them into 'combined models' that were used to check the compatibility of native models or to detect clashes between them. With BIM, the changes to design plans and models are not made to these combined models but they first need to be made to the 'native models' (which can then be united again). Designers do not then work with the same model but they make different versions of the combined model by using their own software.

First, we analysed two ways of using BIM models collaboratively during the project. The first one was a "mechanical" clash detection organized by the BIM expert, and the second was a design collaboration at two one-day design meetings. They presented two ways of using the BIM models. We wanted to understand how the use was organized and how different partners saw these uses. In particular, the "mechanical" clash detection produced tensions which were clear in the events that we followed. The one-day design meetings were analysed in a more detailed way. First, topics discussed during these meetings were identified, and who brought each topic out, and who participated in the discussion on it. We further analysed whether the issue in question was a presentation of what had been done, or a problem that was discussed and handled in the meeting (problem solving). Finally, we analysed if and how BIM models were used. By using Tory et al., 2008 and Ewenstein and Whyte, 2009 as background, we analysed different forms of indexicality in these meetings. We selected two exemplary topics from each of the two meetings. We first identified the expressions of indexicality that were found. Five forms were identified: 1) looking intensively at the BIM model on the screen, 2) demonstrative pronouns referring to the BIM model on the screen, 3) pointing with a finger or with a laser pointer at the model on the screen, 4) pointing with the cursor to certain places in the 
model, 5) moving the BIM model which included sub classes: locating, zooming, rotating, shifting, and cutting the 3D BIM model. Quantitative measures were counted, not for comparative purposes, but in order to show a strong use of indexicality during these meetings.

During a construction project, there are many smaller-scale design meetings at which, for example, structural engineers might solve problems with HVAC engineers when combined models can be used. However, we think that the ways of using BIM that we analysed bring out central insights of collaborative uses of BIM.

\section{The first way of using BIM: a "mechanical" clash detection organized by the BIM expert}

We found two main ways of collaboratively developing and sharing BIM models in the project. Both of these uses treated BIM models as intermediary objects, that is, modifiable and updatable models developed in stages during the project. The first way was an "official" clash detection organized by a BIM expert representing the contractor. This meant that all design partners (architects, HVAC engineers, and structural engineers) were supposed to update their own "native" design models within certain time intervals. These native models were then put together by the BIM expert into a combined model using specific BIM software for this kind of a checking: Solibri Model Checker (see Table 3 above). The software showed clashes between different native models, such as ventilation pipes going through windows. The BIM expert checked the combined model he produced and picked up these kinds of clashes by using the Solibri Model Checker, and/or picked up these clashes on a separate Excel sheet with a screenshot picture from the BIM model. He produced a list of clashes and marked separately which of the design partners should check each clash in question. The Excel sheet (that is, the clash detection list) was then e-mailed to all the design partners who were supposed to update and modify their models accordingly.

When the BIM expert made the combined model explaining why he did what he did, we observed. He characterized the picking up of clashes produced by the software as a quite routine kind of work. At the planning meeting, he questioned whether he was the right person to undertake this checking for the all the design partners. He was oriented to technical issues concerning the functionalities of the software, and was not an expert of either design, or of organizing the work of designers. The main challenge for him was to get the native models from each design discipline in time. He had to recreate the combined model when not all of the native models were in the project bank in time. He also set a certain tolerance of errors with the software. He had agreed with the HVAC engineers and the project manager to allow clashes which were less than 25 millimetres. The BIM expert explained, however, that there should be a zero tolerance for errors but that he must follow what has been agreed to.

"... if I remember right, at the last meeting when I was always urging to have too 
tight rules, HVAC said that it produces too many notifications of clashes. So, I said ok, it is not hard to change them. We can settle for 25 [mm] even though honestly we should have a zero tolerance [for clashes]!"

When we asked whether the zero tolerance would produce unnecessary notifications (of clashes), he said emphatically: "You know those unnecessary notifications - not one notification is unnecessary!"

This use of BIM models produced several tensions. These tensions became obvious when we followed a meeting at which the HVAC engineers went through the list of clashes produced by the BIM expert. The HVAC engineers maintained that the list did not show clashes correctly, mainly because the native models had already been updated after making the combined model. There were also some clashes that needed to be repaired. The HVAC engineer in charge of the work commented to the other HVAC engineers that overall, however, the changes required were not considerable. He had even made a list of his own "because I was not animated by what X [the BIM expert] had done". The HVAC engineer also got some comments from the structural engineer and he said that "they [these comments] contain much more critical notifications [compared to comments by the BIM expert]". During the meeting, the topic of the tolerance level for clashes was brought out. One of the engineers asked whether all the small clashes need to be fixed. The HVAC engineer in charge of the work answered "no" to this question: "We do not need to do anything to clashes of that size if there is the room for them to be there". The changes would only have taken quite a lot of time, and would not change the design models in any relevant sense. According to the HVAC engineers, many of these clashes were caused by un-updated models, or insignificant clashes detected by the software. The engineers thought that actually there was room for them.

Clearly, then, the BIM expert and the HVAC engineers had a different perception of the clashes, and what should be done about them. However, the HVAC engineers did not contact the BIM expert directly on these problems. The BIM expert was not content with the collaboration either because he had problems getting updated models from the designers in time. On the other hand, he emphasized with the project manager and the contractor that this kind of a clash detection is needed. In their opinion, problems and clashes in the design models become costlier if sorted out later in the construction phase. Because of this, the BIM expert would have liked to have a zero tolerance for errors. The BIM expert needed to rely on the clashes produced by the software and (quite understandably) was not able to evaluate if all of these clashes were actual design problems or not. The HVAC engineers, on the other hand, wanted to avoid the extra work of fixing all the details of the models if they did not see them as causing problems at the construction site, or if they did not have extra resources for that kind of a fine-tuning of the models.

The interaction between the BIM expert, the project manager, and the designers 
can be characterized as "scripted coordination" (Engeström et al., 1997; Puonti 2004). Each partner followed their own "script" without doing much collaboration even when there were obvious problems and different interpretations of the situation between the parties.

\section{The second way of using BIM: parallel collaboration in face-to-face design meetings}

BIM models as intermediary objects were also used more collaboratively in the project. The project manager had decided that in addition to the collection of clash detection lists, face-to-face design meetings with all the design partners were needed. During the project they had two one-day meetings (see Table 4. and in more detail Section 7 below).

Table 4. Participants and main features of two one-day design meetings. Note: Some topics were brought up by two partners.

\begin{tabular}{|c|c|c|c|c|}
\hline Meeting & Participants & $\begin{array}{l}\text { Number } \\
\text { of } \\
\text { topics }\end{array}$ & $\begin{array}{l}\text { Who brought } \\
\text { the topic out } \\
\text { (amount) }\end{array}$ & $\begin{array}{l}\text { Number of } \\
\text { presentations } \\
\text { or problem- } \\
\text { solving items }\end{array}$ \\
\hline $\begin{array}{l}\text { Meeting } 1 \\
7,5 \text { hours }\end{array}$ & $\begin{array}{l}\text {-Main designer } \\
\text { (architect) } \\
\text {-Project manager } \\
\text {-Structural engineer } \\
\text {-3 HVAC engineers } \\
\text { (water, general, } \\
\text { electricity) } \\
\text {-4 Other } \\
\text { representatives of the } \\
\text { contractor (HVAC, } \\
\text { production, planning, } \\
\text { maintenance) }\end{array}$ & 90 & $\begin{array}{l}\text {-Main designer } \\
(38) \\
\text {-Structural } \\
\text { engineer (19) } \\
\text {-Project manager } \\
(18) \\
-3 \text { HVAC } \\
\text { engineers (13) } \\
\text {-4 Other (12) }\end{array}$ & $\begin{array}{l}-46 \text { Presentation } \\
-44 \text { Problem } \\
\text { solving }\end{array}$ \\
\hline $\begin{array}{l}\text { Meeting } 2 \\
7 \text { hours }\end{array}$ & $\begin{array}{l}\text {-Main designer } \\
\text { (architect) } \\
\text {-Project manager } \\
\text {-Structural engineer } \\
\text {-2 HVAC engineers } \\
\text { (electricity, general) } \\
\text {-4 Other } \\
\text { representatives of the } \\
\text { contractor (HVAC, } \\
\text { production, planning, } \\
\text { maintenance) } \\
\text { - trainee }\end{array}$ & 87 & $\begin{array}{l}\text {-Main designer } \\
(32) \\
\text {-Structural } \\
\text { engineer (25) } \\
\text {-Project manager } \\
\text { (7) } \\
-2 \text { HVAC } \\
\text { engineers (5) } \\
\text { - Representative } \\
\text { of the contractor } \\
\text { (production) (19) } \\
\text {-3 Other (6) } \\
\end{array}$ & $\begin{array}{l}\text {-54 Presentation } \\
\text {-33 Problem } \\
\text { solving }\end{array}$ \\
\hline
\end{tabular}


The function of the meetings was different from the clash detection organized by the BIM expert. The topics were brought out by the designers themselves, especially by the main designer, or by the project manager, or other partners representing the contractor. The 3D BIM model (the combined model) was used throughout both of these meetings. Sometimes the same model was used as a 2D figure, especially when they were discussing the plan for the demolition work at the end of the first meeting. The combined model was used to inform others about the problem or what had been done ("presentation"), or also to discuss and ponder how to solve these problems ("problem solving"). The project manager called these meetings "fitting together" meetings. They also looked at clashes between the different models. Mostly, however, they concentrated on the topics they knew would produce problems. For example, if they knew that some areas were very tight for all the pipes needed there, they pondered the main solutions for the problem. Clashes were indications of a problem and the focus was on these problems, not on clashes.

For these meetings all design partners had updated their own disciplinary design models (native models) which were united into a combined model using Tekla BIM Sight software (see Table 3 above). The technical procedure was quite similar to the clash detection done by the BIM expert (see Section 5) although the combined model was produced with a different software package. The combined model was used in the faceto-face meetings for discussing design problems in the plans. These meetings were quite burdensome. Even if most of the participants needed to engage quite actively at the meeting, some of the participants - for example the person in charge of maintenance had only a few issues on which to contribute during the day. Even if the meetings were long (about seven hours each) and intensive, there was insufficient time to cover all the issues on the agenda. These meetings represented "parallel collaboration" which can be compared to the scripted coordination characteristic of "official" clash detection where the designers and the BIM expert were sequentially passing information to each other (see Section 5). Parallel collaboration means that the partners worked intensively at the same time around a shared object, in this case problems with design plans presented according to a combined design model (Engeström et al., 1997; Puonti 2004).

In both these ways of using BIM, that is, in mechanical clash detection, and its use at face-to-face meetings, BIM models provided a means of versioning design plans together. Both were used then as ways of using BIM models as co-developed intermediary objects, that is, they were used as stepping stones for subsequent versions of the plan. A central question for the construction projects seems to be how these collaborative uses are organized, that is, what is the aim of this use, who is coordinating it, and how are combined models constructed and used. A 'mechanical' clash detection and the parallel collaboration in the face-to-face meetings had different functions within the project. The former emphasized the point of view of the contractor, represented by the BIM expert, to have design plans to the construction site that were as finalized and as flawless as possible. The latter emphasized the need of the designers to fit their plans together and 
solve those design problems that they treated as critical.

\section{Indexical uses of BIM models in face-to-face design meetings}

In observing the face-to-face design meetings, it became clear that BIM models provide a strong organizing role and a tangible means for collaboration. Even when these BIM models themselves are virtual (that is, digitally produced representations of the upcoming building) they were used indexically during the meetings.

The idea of two one-day face-to-face design meetings was that the project partners needed to come together with all the main design partners (architects, structural engineers, HVAC engineers) and representatives of the constructor to check the situation with the design problems. Designers had several smaller meetings during the project (with two or three partner organizations). The aim of the day-long meetings was to have all relevant partners checking the status of plans together. A prominent feature of these meetings was the central role of BIM models in structuring the work and the problem solving in them. Literally, for most of the time at the day-long meetings, the designers were looking intensively at the combined model which was projected and zoomed on a wallmounted screen, and presenting and discussing the problems of the design and their solutions (see Figure 1). An exception were those participants to whom the issue in question was not relevant, in which case they were looking at their own computers instead of looking at the model in the screen. The principal designer (or the structural engineer for a while) used the BIM software to move and zoom the combined model on those places in the 3D-model which they were discussing.

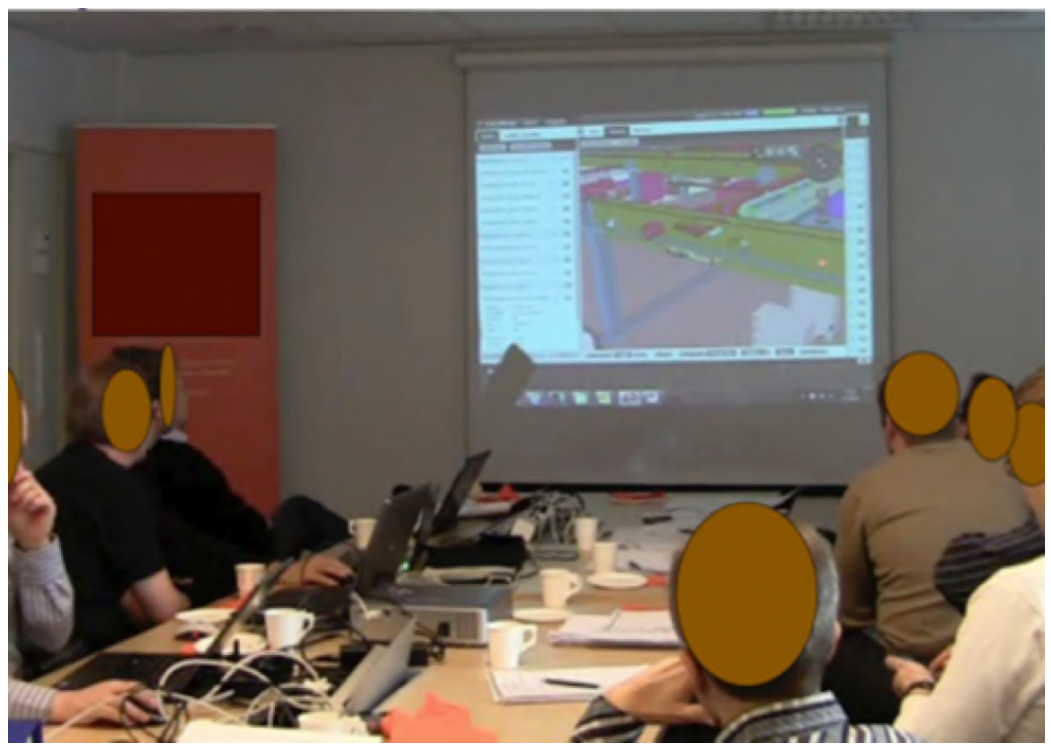

Figure 1. Designers discussing and using the combined model in an intensive one-day design meeting. 
In order to analyse the role of indexical uses of the BIM model more in detail during these meetings, we selected two exemplary topics (one about a presentation and another on problem solving) from each meeting. The analysis is presented in Table 5.

Table 5. The amount of indexicality within four exemplary topics dealt with in the two one-day meetings.

\begin{tabular}{|c|c|c|c|c|c|c|}
\hline $\begin{array}{l}\text { Topic (which } \\
\text { meeting) } \\
\text { (presentation/P } \\
\text { or problem } \\
\text { solving/PS) } \\
\text { Length }\end{array}$ & $\begin{array}{l}\text { Initiator and } \\
\text { number of } \\
\text { other } \\
\text { commentators }\end{array}$ & $\begin{array}{l}\text { Duration } \\
\text { or } \\
\text { pointing } \\
\text { (no.) } \\
\text { (Finger } \\
\text { or laser) }\end{array}$ & $\begin{array}{l}\text { Duration } \\
\text { or a } \\
\text { number } \\
\text { of } \\
\text { pointing } \\
\text { (no.) } \\
\text { (Cursor) }\end{array}$ & $\begin{array}{l}\text { A number of } \\
\text { demonstrative } \\
\text { pronouns }\end{array}$ & $\begin{array}{l}\text { Duration } \\
\text { of } \\
\text { looking } \\
\text { at the } \\
\text { BIM } \\
\text { model at } \\
\text { the } \\
\text { screen }\end{array}$ & $\begin{array}{l}\text { Number of } \\
\text { movements } \\
\text { of the } \\
\text { model }\end{array}$ \\
\hline $\begin{array}{l}\text { 1.Must the } \\
\text { pilaster } \\
\text { be cut or not? } \\
\text { Meeting } 1(\mathrm{P}) \\
\text { 2min 51s }\end{array}$ & $\begin{array}{l}\text { Structural } \\
\text { engineer }+ \\
1 \text { commentator }\end{array}$ & $\begin{array}{l}2 \min 51 \\
\mathrm{~s}\end{array}$ & 2 times & 60 & $2 \min 51 \mathrm{~s}$ & 12 \\
\hline $\begin{array}{l}\text { 2.Searching a } \\
\text { place for flues } \\
\text { Meeting } 1 \text { (PS) } \\
\text { 14min 15s }\end{array}$ & $\begin{array}{l}\text { Main designer } \\
+ \\
5 \\
\text { commentators }\end{array}$ & 10 times & $7 \mathrm{~min} 30 \mathrm{~s}$ & 131 & $\begin{array}{l}11 \mathrm{~min} \\
20 \mathrm{~s}\end{array}$ & 61 \\
\hline $\begin{array}{l}\text { 3. How small } \\
\text { flues are } \\
\text { planned? } \\
\text { Meeting } 2(\mathrm{P}) \\
\text { 3min 13s }\end{array}$ & $\begin{array}{l}\text { Main designer } \\
+ \\
5 \\
\text { commentators }\end{array}$ & 2 times & $3 \min 13 s$ & 38 & $3 \min 13 s$ & 34 \\
\hline $\begin{array}{l}\text { 4.Broadening of } \\
\text { the flues and } \\
\text { how to get to } \\
\text { the rooms } \\
\text { upstairs? } \\
\text { Meeting } 2 \text { (PS) } \\
9 \text { min } 37 \mathrm{~s}\end{array}$ & $\begin{array}{l}\text { Main designer } \\
+ \\
4 \\
\text { commentators }\end{array}$ & 15 times & $4 \mathrm{~min} 49 \mathrm{~s}$ & 84 & $9 \min 14 \mathrm{~s}$ & 67 \\
\hline
\end{tabular}

Topics 1 and 3 are examples of a presentation of a problem. With Topic 1, the structural engineer mainly talked and described a problem of whether a large pilaster should be cut, or could it be kept as one by making flues narrower. With Topic 3 , the main architect described how it was planned to make a bunch of small flues. In both of these examples, the main group of designers were looking at the BIM model on the screen for most of the time, except for short glances at other people. During both of these topics, 
practically all the time (about three minutes in both instances), there was someone from among the participants indexically pointing towards the model at specific spots discussed. In Topic 1, the structural engineer started by pointing with a finger at the model and then continued with a laser pointer while explaining the topic. In Topic 3, the main architect pointed to the model with a cursor while explaining what had been done. In both topics there was also frequent use of demonstrative pronouns pointed to the model (here, there, that, ...) while talking (60 times in Topic 1 and 38 in Topic 3). The model was moved actively in both topics, including locating, zooming, rotating, shifting, and cutting. In Topic 1 there were fewer of these movements basically when the topic introduced just one problematic place from different angles.

Topic 2 was about some of the main flues that were located in places with not much room for pipelines and for furniture. The main architect started the discussion, and then the HVAC engineer made comments and questions based on problems from his point of view, and after that the discussion continued with others. Most of the time they were looking at the screen. There were short intervals which interrupted this when they were negotiating on how to solve the problem in question. Even during these short intervals, many of them glanced at the screen. While they discussed this, the main architect moved the BIM model itself almost constantly to those places that they were discussing. There were 61 such movements in total, comprising locating, zooming, shifting, rotating, and cutting.

Topic 4 was about a tight place where there were so many pipes that on the one hand, it was hard to keep the structures durable (if there were many pipes going through them), but on the other hand, have enough room for these pipes to go to a classroom upstairs. The main architect started an intensive discussion with the HVAC engineer, the structural engineer, and a project manager. For most of the time (over nine minutes), they were looking at the screen. An exception to this was a short interval of jokes. The use of indexical pointing was frequent. For about half of the time (4 min $49 \mathrm{~s}$ ), the main architect pointed out certain places of the model with the cursor, and others used their fingers to point at the model several times (15 in total). The main architect moved the BIM model constantly (67 movements in total). In both Topics 2 and 4, the use of demonstrative pronouns (targeted at the BIM model) was frequent (131 times in Topic 2 and 84 in Topic 4).

In Table 6 is another short excerpt (lasting 33 seconds), showing the frequency and the nature of indexicality during the meeting. In it, a HVAC engineer asked a structural engineer where to have a void for the ducts. This short excerpt contained 12 demonstrative pronouns targeted at the model. The principal designer handled and moved the BIM model on the screen for everyone according to the instructions of the HVAC engineer (five movements during this excerpt).

Table 6. An example of indexical pointing in a one-day design meeting at which a HVAC engineer asked about a specific place where it would be possible to get ducts and pipes 
through structures (a part of the issue 'effects on moving the flue').

\begin{tabular}{|c|c|c|}
\hline $\begin{array}{l}\text { Talk (demonstrative } \\
\text { pronouns bolded) }\end{array}$ & Indexical pointing & $\begin{array}{l}\text { Movements with the BIM } \\
\text { model }\end{array}$ \\
\hline $\begin{array}{l}\text { HVAC engineer: 'Yes, it is } \\
\text { this one here, if you can } \\
\text { take it up a bit. You cannot } \\
\text { see all the items yet. Here- } \\
\text { if we go with ducts through, } \\
\text { with pipes through, so the } \\
\text { pillar is here, the middle } \\
\text { third is here. Can we go } \\
\text { through with ducts here? } \\
\text { Water and drain. There you } \\
\text { can actually see water and } \\
\text { a drain, to make it clear that } \\
\text { I have changed it here } \\
\text { when here starts that } \\
\text { middle third this way. How } \\
\text { is it with these kinds, can } \\
\text { we make a void here?' }\end{array}$ & $\begin{array}{l}\text { HVAC engineer points with } \\
\text { a laser pointer related } \\
\text { places in the model } \\
\text { Most of the designers were } \\
\text { oriented towards and } \\
\text { staring to the screen. }\end{array}$ & $\begin{array}{l}\text { Principal designer (PD) } \\
\text { moves (5) the model } \\
\text { according to the cues by } \\
\text { the HVAC engineer: } \\
\text {-cutting } \\
\text {-zooming } \\
\text {-shifting } \\
\text {-zooming } \\
\text {-cutting }\end{array}$ \\
\hline
\end{tabular}

The use of BIM models reminds us of the use of 2D paper drawings or CAD models depicted in research on design collaboration with a lot of indexicality and collaborative talk around plans and sketches. In this sense the use can be compared to the role of sketches and drawings as 'conscription devices' in design work (Henderson 1991). Among the differences compared with old 2D/3D CAD models is that a) different design models can be put together as a 3D representation (a difference to old CAD models), and $b$ ) it can be seen from different angles (a difference to 2D models). The plans of the building can be zoomed and moved while looking and thinking about design problems in collaborative meetings. Although the model is virtual, it permits a tangible way of dealing with the design problems. This was shown by the strong organizing role of the BIM model during the faceto-face meetings. The spatiality (zooming and moving) and the indexicality found in the meetings cannot be reduced to visuality alone but is rather some kind of spatial problem solving. In this sense, the BIM models are like miniature models (with 3D features) by which we mean that spatial relationships and problems between different native models can be observed and examined with them. It is not only clashes between different native models that are important, but the combined model depicts problematic areas that can be seen and investigated together. Even if these models are not material in the same sense of real structural elements of the building (or paper drawings), they are an external (material) means for designers to examine the design plans. A common phrase among designers in their meetings was to say: "This needs to be examined more". BIM models 
are central building blocks of doing the work in face-to-face meetings and reconciling different models. When analysing the problems in the model, the designers also think and imagine the relationships and compatibility of real structural elements of buildings, familiar to them. In addition, the model provides information on the qualities of the elements. This knowledge becomes fused in the perception of structures in the model. The constructability and uses of a building is thought through and analysed through the combined 3D model. In this sense, we suggest that BIM models provide a novel kind of virtual materiality that differs from what we find in paper drawings or CAD models.

\section{Conclusions}

Digital technologies and uses of digital objects are changing the ways designers do their work and collaborate. However, it is easy to exaggerate these changes. In this paper we reported on analysis of these changes within construction design provided by building information modelling (BIM) technologies. BIM is an interesting phenomenon since it has had a long development background in CAD-CAM technologies, product models, and standards. However, the use of BIM technologies in construction projects has become common only in recent years. The changes are not abrupt but are the result of a long evolution which is still ongoing and the future development of which is not known (Miettinen and Paavola, 2014).

There is a need to develop new conceptualizations to make sense of these changes. An important function provided by the BIM technologies is the use of combined models on the basis of 'native' models produced separately with special software by each design discipline. New digital tools have provoked discussions on the materiality of digital objects. Digital tools enable new ways of transferring, sharing, editing, and modifying data. These options must be interpreted in those practical and institutional contexts in which these tools are used. Above we have analysed how digital design models are used in a construction project in design collaboration. The use in the face-to-face meetings especially provides a tangible means of working with design plans. We suggest that BIM models as co-developed intermediary objects provide novel forms of 'virtual materiality'. The virtual materiality of these models is visible in their frequent indexical use, and how they allow and contribute to joint problem solving in the meetings. BIM models reproduce the visual tangibility of technical drawings but on a 3D level allowing different models to be combined and manipulated, like rotating and zooming, of combined model transcending boundaries of individual design disciplines. The resemblance of the 3D model to the final material building is higher compared to the 2D drawings, and with BIM models the designers can analyse and explore better the spatial relationships of a building than with the drawings. Research on design work has emphasized that designers point out, refer, annotate, and reflect on the visual artefacts while discussing design problems in face-to-face meetings. The high frequency of indexicality became visible also in the face-to-face meetings in which BIM models were used. 
We found that one key phenomenon in the study of collaborative design is an object formation or object construction, that is, a gradual development of the early ideas of a product through various co-developed intermediary objects into a comprehensive set of models and plans that make the construction of the building possible. Our analysis highlights the need to conceptualize more these phases of the construction of the object (cf. Vinck and Jeantet, 1995; Ewenstein and Whyte, 2009; Deken and Lauche, 2010). Ewenstein and Whyte (2009) analysed the use of visual representations in the construction project and highlighted the epistemic role of objects because they are characterized by a 'lack' of incompleteness and are targeted to dynamic knowledge development in these projects. Our analysis of the use of BIM models complies with the unfolding and dynamic nature of these objects. But rather than seeing them as abstract "epistemic objects" we argue that they function as dynamic but tangible intermediary objects. BIM tools provide a new means of working with editable models which are constructed collaboratively. BIM technology provides certain means of working collaboratively, and companies are developing ways of organizing its uses. The design of a building is based on an established division of labour. Different design disciplines work on their own 'sub-objects', native models, which they develop largely independently using their own tools, software and expertise. Constant interaction between these parallel design processes by means of combined models is needed to develop a realizable overall plan for the construction of a building.

At the centre of the building design process is the parallel design of partial, interdependent, incomplete, reworkable and imaginary external representations or datarich plans for the forthcoming building. They are partial because they represent a part of the building (like pipelines, or a structural model). They are interdependent because they need to be compared and integrated into other partial representations and models. They are incomplete because they will be further transformed in the process. They are imaginary because they represent something that does not exist in its final physical form and can therefore be changed relatively easily. The partial models are united into a combined model that constitutes an intermediary object that plays a central means in the interdisciplinary design collaboration.

BIM is clearly a focal part of the changes happening in the construction industry. For the designers and design companies, BIM provides a new set of instrumentalities, the uses of which are negotiated between companies and developed in construction projects. In the construction industry, the BIM-related software tools are reconfigured not only by the firms for their own use, but also renegotiated in projects when actors with different traditions and tools are brought together. BIM technologies are used in parallel with other tools and technologies, and the stakeholders are constantly developing new functions and ways of using BIM technologies. The sharing of disciplinary data with BIM is not complete and technical problems in the sharing often require extra efforts. Many software programs are used in a single project, and digital tools are used in parallel with paper drawings. In addition, the functionality of BIM must be regarded in relation to other software tools and 
traditional, non-BIM tools such as drawings, physical models and sketches. They are intertwined into what Harty and White (2010) call 'hybrid practices', that is, practices in which nondigital and digital tools are used in complementary ways.

In order to understand these changes, traditional conceptions of functions and uses of artefact-mediated activity are a useful starting point but these conceptions must be broadened. General features of digital objects, such as editability and distributedness, have been suggested as contributing to qualitative changes in these functions. In this paper, we suggest that materiality in the form of indexicality and spatial tangibility get a new meaning with digital objects. In addition, new functionalities are emerging in different phases of a construction process which gradually change the construction process.

\section{Acknowledgements}

This article has been written through several stages and with several intermediary objects. The first draft of the paper was presented at the EGOS conference in Montreal, Canada in 2013 (in a session convened by Jannis Kallinikos, Paul Leonardi and Bonnie Nardi). Thank you to all of them, and especially to Aleksi Aaltonen, Jannis Kallinikos, Eugenia Cacciatori, Carole Groleau, Jennifer Whyte, our colleagues at CRADLE, and reviewers of the paper, for useful comments on versions of the paper.

\section{References}

Alhava, Otto; Laine, Enni; and Kiviniemi, Arto (2015). Intensive big room process for cocreating value in legacy construction projects. Journal of Information Technology in Construction (ITcon), Special Issue: ECPPM 2014, vol. 20, pp. 146-158.

Alves, Thais da C. L.; and Tsao, Cynthia C. Y. (2007). Lean construction-2000 to 2006. Lean Construction Journal, vol. 3, no. 1, pp. 46-70.

Becerik-Gerber, Burcin; and Rice, Samara (2010). The perceived value of building information modeling in the U.S. building industry. Journal of Information Technology in Construction, vol. 15, pp. 185-201.

Bishop, Dan; Felstead, Alan; Fuller, Allison; Jewson, Nick; Unwin, Lorna; and Kakavelakis, Konstantinos (2009). Constructing learning: adversarial and collaborative working in the British construction industry. Journal of Education and Work, vol. 22, no. 4, pp. 243-60.

Blanchette, Jean-François (2011). A material history of bits. Journal of The American Society for Information Science and Technology, vol. 62, no. 6, pp. 1042-1057. 
Boujut, Jean-Francois; and Blanco, Eric (2003). Intermediary objects as a means to foster co-operation in engineering design. Computer Supported Cooperative Work, vol. 12, no. 2, pp. 205-219.

Bresnen, Mike; and Harty, Chris (2010). Editorial: objects, knowledge sharing and knowledge transformation in projects. Construction Management and Economics, vol. 28 , no. 6 , pp. 549-555.

Bucciarelli, Louis L. (1994). Designing Engineers. Cambridge, MA: The MIT Press.

Bucciarelli, Louis L. (2002). Between thought and object in engineering design. Design Studies, vol. 23, no. 3, pp. 219-231.

Christensen, Lars Rune (2014). Practices of stigmergy in the building process. Computer Supported Cooperative Work (CSCW), vol. 23, no. 1, pp. 1-19.

Christensen, Lars Rune; and Harper, Richard H. (2016). The Many Faces of Computational Artifacts. In COOP 2016: Proceedings of the 12th International Conference on the Design of Cooperative Systems, 23-27 May 2016, Trento, Italy. Springer International Publishing, pp. 93-106.

Clark, Herbert H. (2005). Coordinating with each other in a material world. Discourse Studies, vol. 7, nos. 4-5, pp. 507-525.

Crotty, Ray (2012). The impact of Building Information modelling. Transforming Contruction. London: Spon Press.

Davenport, Thomas H. (1998). Putting the enterprise into the enterprise system. Harvard Business Review, vol. 76, no. 4, pp. 121-131.

Deken, Fleur; and Lauche, Kristina (2010). Expansive learning and new practice creation: a conceptualization of collaborating in inter-organizational product innovation. In Proceedings of the Second International Symposium on Process Organization Studies, pp. 1-33.

Deken, Fleur; and Lauche, Kristina (2014). Coordinating through the development of a shared object: an approach to study interorganizational innovation. International Journal of Innovation and Technology Management, vol. 11, no. 1, 1440002 (24 pages).

Eastman, Charles M.; Teicholz, Paul; Sacks, Rafael; and Liston, Kathleen (2011). BIM Handbook (2nd Edition) A Guide to Building Information Modeling for Owners, Managers, Designers, Engineers and Contractors. New Jersey: John Wiley \& Sons.

Eckert, Claudia; and Boujut, Jean-Francois (2003). The role of objects in design cooperation: Communication through physical or virtual objects. Computer Supported Cooperative Work, vol. 12, no. 2, pp. 145-151. 
Ekbia, Hamid R. (2009). Digital artifacts as quasi-objects: Qualification, mediation, and materiality. Journal of the American Society for Information Science and Technology, vol. 60, no. 12, pp. 2554-2566.

Engeström, Yrjö; Brown, Katherine; Christopher, L; and Gregory, Judith (1997). Coordination, cooperation, and communication in the courts: Expansive transitions in legal work. In M. Cole, Y. Engeström and O. Vasquez (eds.) Mind, Culture and Activity: Seminal Papers from the Laboratory of Comparative Human Cognition. Cambridge University Press, Cambridge, pp. 369-388.

Ewenstein, Boris; and Whyte, Jennifer (2009). Knowledge practices in design: The role of visual representations as 'epistemic objects'. Organization Studies, vol. 30, no. 1, pp. 7-30.

Faulkner, Philip; and Runde, Jochen (2011). The social, the material, and the ontology of non-material technological objects. A paper presented at the 27th EGOS Colloquium, Gothenburg, July 6-9.

Fetterman, David M. (2010). Ethnography: Step-by-step. Third Edition. Los Angeles: Sage.

Goodwin, Charles (2000). Action and embodiment within situated human interaction. Journal of Pragmatics, vol. 32, no. 10, pp. 1489-1522.

Harty, Chris; and Whyte, Jennifer (2010). Emerging hybrid practices in construction design work: Role of mixed media. Journal of Construction Engineering and Management, vol. 136, no. 4, pp. 468-476.

Henderson, Kathryn (1991). Flexible sketches and inflexible data bases: Visual communication, conscription devices, and boundary objects in design engineering. Science, Technology, \& Human Values, vol. 16, no. 4, pp. 448-473.

Henderson, Kathryn (1999). On Line and on Paper: Visual Representations, Visual Culture, and Computer Graphics in Design Engineering. Cambridge, MA: The MIT Press.

Hindmarsh, Jon; and Heath, Christian (2000). Embodied reference: A study of deixis in workplace interaction. Journal of Pragmatics, vol. 32, no. 12, pp. 1855-1878.

Hui, Yuk (2012). What is a digital object?. Metaphilosophy, vol. 43, no. 4, pp. 380-395.

Hutchins, Edwin (2005). Material anchors for conceptual blends. Journal of Pragmatics, vol. 37 , no. 10 , pp. 1555-1577.

Ilyenkov, Evald V. (1977). Dialectical Logic: Essays on Its History and Theory. Moscow: Progress Publishers. 
Kallinikos, Jannis (2002). Reopening the black box of technology artifacts and human agency. In R. Galliers and L. Markus (eds.): 23rd ICIS, Barcelona, Spain, 14-16 December, pp. 287-294.

Kallinikos, Jannis; Aaltonen, Aleksi; and Marton, Attila (2010). A theory of digital objects. First Monday, vol. 15, 6-7 June.

Kaptelinin, Victor; and Bannon, Liam J. (2012). Interaction design beyond the product: Creating technology-enhanced activity spaces. Human-Computer Interaction, vol. 27, no. 3, pp. 277-309.

Kaptelinin, Victor; and Nardi, Bonnie A. (2006). Acting with Technology: Activity Theory and Interaction Design. Cambridge, Mass: The MIT Press.

Korpela, Jenni; Miettinen, Reijo; Salmikivi, Teppo; and Ihalainen, Jaana (2015). The challenges and potentials of utilizing building information modelling in facility management: The case of the Center for Properties and Facilities of the University of Helsinki. Construction Management and Economics, vol. 33, no. 1, pp. 3-17.

Kuutti, Kari (2011). Out of the shadow of Simon: Artifacts, practices, and history in design research. Proceedings of the Doctoral Education in Design Conference. Hong Kong 23.-25.5.2011.

Laakso, Mikael; and Kiviniemi, Arto (2012). The IFC standard - A review of history, development, and standardization. Journal of Information Technology in Construction (ITcon), vol. 17, no. 9, pp. 134-161.

Lahdenperä, Pertti (2012). Making sense of the multi-party contractual arrangements of project partnering, project alliancing and integrated project delivery. Construction Management and Economics, vol. 30, no. 1, pp. 57-79.

Latour, Bruno (1986). Visualization and cognition. Knowledge and society, vol. 6, no. 6, pp. $1-40$.

Leonardi, Paul M. (2010). Digital materiality? How artifacts without matter, matter. First Monday, vol. 15, 6-7 June.

Leontjev, Aleksei N. (1978). Activity, Consciousness and Personality. Prentice Hall, Englewood Cliffs.

Love, Peter E.; Matthews, Jane; Simpson, lan; Hill, Andrew; and Olatunji, Oluwole A. (2014). A benefits realization management building information modeling framework for asset owners. Automation in Construction, vol. 37, pp. 1-10.

Manovich, Lev (2001). The Language of New Media. Cambridge, Mass.: The MIT Press.

Miettinen, Reijo; and Paavola, Sami (2014). Beyond the BIM utopia: Approaches to the development and implementation of building information modeling. Automation in Construction, vol. 43, pp. 84-91. 
Miettinen, Reijo; and Paavola, Sami (in press) Reconceptualizing object construction: The dynamics of building information modelling in construction design. Information Systems Journal.

Orlikowski, Wanda J. (2007). Sociomaterial practices: Exploring technology at work. Organization Studies, vol. 28, no. 9, pp. 1435-1448.

Peirce, Charles S. (1931-1958) [CP volume.paragraph]. Collected Papers of Charles Sanders Peirce, Volumes 1-6, C. Hartshorne and P. Weiss (eds.), Volumes 7-8, A. W. Burks (ed.). Cambridge, Mass.: Harvard University Press.

Puonti, Anne (2004). Tools for collaboration: Using and designing tools in interorganizational economic-crime investigation. Mind, Culture, and Activity, vol. 11, no. 2, pp. 133-152.

Schmidt, Kjeld; and Wagner, Ina (2002). Coordinative artifacts in architectural practise. In Blay-Fornarino at al. (eds.): Cooperative Systems Design: A Challenge of the Mobility Age. [Proceedings of the Fifth International Conference on the Design of Cooperative Systems (COOP 2002), Saint Raphaël, France, 4-7 June 2002], IOS Press, Amsterdam, pp. 257-274.

Schmidt, Kjeld; and Wagner, Ina (2004). Ordering systems: Coordinative practices and artifacts in architectural design and planning. Computer Supported Cooperative Work, vol. 13, no. 5, pp. 349-408.

Stewart, James K.; and Williams, Robin (2005). The wrong trousers? Beyond the design fallacy: Social learning and the user. In H. Rohracher (ed.) User Involvement in Innovation Processes. Strategies and Limitations from a Socio-Technical Perspective. Munich: Profil-Verlag.

Subrahmanian, Eswaran; Monarch, Ira; Konda, Suresh; Granger, Helen; Milliken, Russ; and Westerberg, Arthur (2003). Boundary objects and prototypes at the interfaces of engineering design. Computer Supported Cooperative Work (CSCW), vol. 12, no. 2, pp. 185-203.

Succar, Bilal (2009). Building information modeling framework: A research and delivery foundation for industry stakeholders. Automation in Construction, vol. 18, pp. 357375.

Tory, Melanie; Staub-French, Sheryl; Po, Barry A.; and Wu, Fuqu (2008). Physical and digital artifact-mediated coordination in building design. Computer Supported Cooperative Work, vol. 17, no. 4, pp. 311-351.

Vinck, Dominique (2011). Taking intermediary objects and equipping work into account in the study of engineering practices. Engineering Studies, vol. 3, no. 1, pp. 25-44. 
Vinck Dominique; and Jeantet Alain (1995). Mediating and commissioning objects in the sociotechnical process of product design: a conceptual approach. In D. MacLean, P. Saviotti and D. Vinck (eds) Management and New Technology: Design, Networks and Strategies. COST Social Science serie. Bruxelles. Commission of European Union, pp. 111-129.

Whyte, Jennifer; and Harty, Chris (2012). Socio-material practices of design coordination: Objects as plastic and partisan. In P. M. Leonardi, B. A. Nardi, and J. Kallinikos (eds.) Materiality and Organizing. Social Interaction in a Technological World. Oxford: Oxford University Press, pp. 196-213.

Yoo, Youngjin; Lyytinen, Kalle; Boland, Richard; Berente, Nicholas; Gaskin, James; Schutz, Doug; and Srinivasan, Nikhil (2010). The next vawe of digital innovation: opportunities and challenges. A Report of the Research Workshop 'Digital Challenges in Innovation Research' (June 8, 2010). http://ssrn.com/abstract=1622170.

\footnotetext{
${ }^{1}$ Indexicality has been emphasized by many researchers close to distributed cognition or situated cognition by pointing out that human beings, even when dealing with conceptual issues are using resources from the material, social and cultural surrounding as an essential part of their activities (see e.g. Goodwin 2000; Hindmarsh and Heath, 2000; Hutchins 2005; Clark 2005)

2 'Virtual materiality' (the latter term referring to tangibility or concreteness) might sound like a contradiction in terms. One of our reviewers pointed this out: "if we accept that it [the BIM model] really is virtual, how can it provide a "novel kind of concreteness"? What do "virtual," and "concrete" and "concreteness" mean in this context?". Our argument is, however, that the uses of BIM models do not follow this kind of a dichotomy but are virtual and concrete at the same time.
} 